\title{
Traditions and Tendencies of the Dagestan Education
}

\author{
Mustafa Isaevich Bilalov \\ Dagestan State University, Makhachkala, Russia \\ Email: mibil@mail.ru
}

Received 7 January 2015; accepted 19 February 2015; published 26 February 2015

Copyright (C) 2015 by author and Scientific Research Publishing Inc.

This work is licensed under the Creative Commons Attribution International License (CC BY). http://creativecommons.org/licenses/by/4.0/

c) (i) Open Access

\begin{abstract}
Modern system of education is filled with contradictions of the age-old traditions and broken reforms, trying to succeed the rhythm of public changes. Moslem education has been instilling in Dagestan and other national republics of the Northern Caucasus, interrupted less than an age of Soviet power. Nowadays, Islamic education is being developed intensive enough, that is why we dare say that Islamic educational institutions of Modern Dagestan have become a component part of All-Russian and International Islamic educational network. Dagestan Islamic education developing tendency brings its negatives into cultural and educational situations. In social consciousness, a negative image of secular sciences is being formed, which prevents Dagestan Education from including into modern education. Consequently, forming a united educational space in the region and its further entry into the world, a number of cultural references are proposed. Taking into consideration an obvious community of historic fates, the regional people will have to realize its deep and mental foundations to determine spiritual monolith. Educational and cultural policy of Dagestan as well as all Moslem Northern Caucasus must proceed from religious tendency, which is becoming more important in modern education. Dagestan educational traditions and tendencies form a concrete and historic integral system, imbued with many contradictions. It takes a united effort from scientists, politicians, organisers of science and education to solve such problems.
\end{abstract}

\section{Keywords}

Religious and Secular Education, Trends and Traditions of the Dagestan Education, The Concepts of Education, The Bologna System, Educational Space

\section{Introduction}

Modern education system is riddled with contradictions of century-old traditions and continuous reforms trying 
to follow the rhythm of social change. Planning, structuring, control during the system in a sustainable, ordered state, while the initiative, innovation, educational experimentation push it to instability and chaos in nonlinear systems. It is a state of chaos that is most characteristic of Russian especially Daghestan education today.

Currently, educational system in Russia in general corresponds to the classical model the origins of which date back to the European pedagogy of the end of XVIII-the beginning of the XIX century. This traditional model requires for a student to move from school base to independent acquisition of knowledge, values and skills of higher order in comparison with the previously absorbed. However, the modern Russian education has a clearly informational nature and is based on reproductive training or use of ready-made knowledge. The content of the training is based mainly on the sciences and includes only time-tested knowledge, so it's drawn into the past. The classic type of thinking according to this model holds to a mechanistic picture of the world with unique solutions of real problems. A vivid expression of the crisis phenomena is the transition of Russian education to the Bologna system.

Referring to the next and as always accompanied by scandals and sensations cycle of school tests in 2013 in Russia, as known as the Unified State Exam. Rosobrnadzor summarized some preliminary results of the mass pupil testing. They again generated a lot of contradictory views on their effectiveness ranging from praise as objective and impartial selection tool for further study at universities and ending with an equally absolute nihilism in evaluating the impact of such work. The Unified State Exam doesn't fulfill the main purpose in all the regions of the Russian Federation without exception: Although quantitative indicators are rising, the quality of education is deteriorating from year to year. The exam itself is accompanied by massive violations. "Over 800 cases of violations committed by the officials in securing and holding the state (final) certification exam in the form of the USE were recorded” [1], says Rosobrnadzor. The improper performance of official duties, which has involved the violations of the USE, the use of mobile phones, the publication of fragments of the CMM materials by the USE participants, weakening of the control over the conduct and organization of the USE, lack of awareness of the organization, errors and irregularities in dealing with the databases of the USE participants are among the main violations.

According to authorities, the largest number of violations was found in the North Caucasus and Central Federal districts. Disciplinary sanctions were imposed on 276 people. 432 people were brought to administrative responsibility ${ }^{1}$. The Republic of Dagestan is among the regions-violators. According to the Minister of Education and Science of the Republic of Dagestan, the number of those who got high scores (80 - 100) on biology exceeds last year's records twice, on mathematics four times. The double-check of more than two thousand works on biology has revealed 600 works decommissioned from the Internet.

Experts in different fields, related to the USE, propose measures that could hold its organization in line with the interests of the society. It is proposed, for example, to make the USE voluntary, to enable graduates several attempts to take the exam, to make the results of the exam confidential, to entrust the exam to non-state structures, to allow universities the selection of various variants of entrance exams...

One can't explain the modern state of education in the republic without referring to its history. Muslim education had been introduced in Dagestan and other national republics of Northern Caucasus for centuries, whichwas interrupted for less than a century of Soviet rule. Today there is an attempt to resume it, when Islamic primary schools, which are educational institutions at the mosque, are functioning in some rural areas along with secular education. The curriculum is based on reading of the Qur'an and teaching writing in Arabic. In addition to reading and writing students study Arabic grammar, the hadiths of the Prophet Muhammad, and basics of mathematics and so on. And these types of educational institutions are being opened in the $21^{\text {st }}$ century. Secular schools are provided not by the state, but by the long tradition established in the Muslim world, when the wealthy people showed charity especially in the field of education.

The first madras as emerged in Dagestan over a thousand years ago-at the end of the $11^{\text {th }}$ century, and eventually they were in almost every large village. By the early $20^{\text {th }}$ century there were 853 Muslim schools with the number of students of 5719, while there were only 1896 students in 26 secular schools, the opening of which began only with the accession to Russia, of which 493 children studied in rural areas, including 25 girls [2].

The system of Islamic education in the Republic of Dagestan now includes 14 Islamic higher educational institutions (over 2600 students) with 43 branches(over 2400 students), 132 madrasas (secondary education) (more than 4400 students), 278 maktabs (primary schools) (about 4000 students) with the whole number of students of about 14,000 people. The present oligarchs or simply “new Dagestani” don't hurry to repair the secular schools, which were built during the Soviet era or construct new ones instead, but are willing to build or finance mosques, 
maktabs, madrasas and Islamic universities for the sake of Islam. Thus, Islamic education in the region is now being developed quite rapidly. You could say that Islamic schools of modern Dagestan have become an integral part of all-Russian and international Islamic educational network.

According to the law "On freedom of conscience, religion and religious organizations", the republican religious organizations that have passed the state registration have an exclusive right to establish the institutions of religious education for the professional training of the clergy and religious personnel. (The Spiritual Administration of Muslims of Dagestan has such a right at the moment). Religious universities and their brunches are subject to mandatory licensing by the Department of licensing, accreditation and supervision in the field of education of the Federal Agency for Supervision in Education and Science. Twelve of fourteen Islamic universities have a valid license from the Ministry of Education and Science of the Russian Federation. All three theological universities also have a license from the Ministry of Education and Science of the Russian Federation. The Ministry is also committed to fund work on the compilation and publication of teaching materials, textbooks and manuals on religious subjects. There is no influence of foreign funds. Over 1000 Dagestani study in Muslim universities abroad in such countries as Syria (256 people), Egypt (185), Turkey (140), Pakistan (96), Saudi Arabia (59), Iran and some others. Several dozen people study in Jordan, Tunisia and some other countries. The main reason of studying abroad is to learn Arabic in the Arabic world.

In 2007 North-Caucasian university centre of Islamic education and science was founded in Makhachkala (NCUCIES). Its founders are the Institute of Theology and religious studies (Makhachkala), Dagestan Islamic university (ex-SKIU), Chechen Islamic institute named after Kadirov and IngushIslamic institute. More than 15 various educational programmes in religious and secular subjects have been developed. ("Prophetical activity and biography of the Prophet”, "Namaz”, "Religious philosophy”, "Hajj”, "History of Arabic”, "Koran”, "History of Arabic countries”, "Hadith”, “Tasrif”, "Islamic practical law”, "Islamic theology”, "Zakah”, "Calligraphy”, and others). Teaching of general secular subjects is poorly organized-there isn't enough financial provision and there is shortage of universities heads' desire to provide part of the secular education.

The tendency of development of Islamic education in Dagestan brings its negatives to the overall situation in culture and education. The negative image of secular sciences is being developed in public conscience. Moreover, curricular and subjects, their content and ways of teaching remain the same and are turned towards the past. Training of qualified teaching staff is discredited against the background of Islamic education-absolute majority of teaching personnel of Dagestan Islamic institutions are graduates of the same institutions or madrasa or selfeducated people. In spite of this fact Dagestan Muslim clergy raises a question about introduction of teaching the basics of Islam to the secular state education insistently and regularly. Its main arguments are: there are some facts of teaching the basics of Orthodoxy culture in some Russian regions, so in Islamic region, which is Dagestan, it is necessary to bring up children in the spirit of traditional Islam to counterbalance the attempts of introduction of Vahhabism and other forms of extremist ideology.

The Law of the Republic of Dagestan "On freedom of conscience, religion and religious organizations", as well as the corresponding federal law, allows the inclusion of disciplines to study the history of world religions, religious morality, ethics and morality in the curriculum of educational institutions of the state system, provided that the study of these disciplines there will be carried without performing religious cult activities (Article 8).In recent years, the Dagestan Scientific and Research Institute of Education has developed, and the Ministry of Education and Science has introduced a number of optional programs and courses, such as "History of World Religions", "Religion and its monuments" and others in the educational process. However, the Muslim clergy insists on the introduction, though optional, of the lessons of Islam, rather than religious disciplines. The Muslim clergy has a negative attitude even to the teaching of these disciplines in the state universities of the republic.

In Islamic schools, particular attention is given to moral education of students. Students' respect to each other is cultivated there. There are no problems of drug addiction, alcoholism, profanity, smoking and crime. In this regard, Islamic schools are much better than secular schools. However, the Dagestan Religious education system as a whole could not resist and repel the Wahhabi ideology and actually lost in this ideological confrontation. The Wahhabis have proved to be more erudite and trained.

Talking about the negative tendencies of the Dagestan education, we cannot ignore the problem "teacherstudent", which has its origins in the epistemological "subject-object" attitude. Who is the true subject of the learning process? How to move away from authoritarian traditions which transform students just in a simple vessel of knowledge and moral values? How to move from a student-recipient to an active and cognitive person? What place does pedagogy of cooperation take in modern education? How to incorporate the tradition of sepa- 
rate education for boys and girls into it? Such range of issues was being solved quite inefficiently in the tradition of Islamic education first, and then by the Soviet system of education. The study of the texts of the Quran lay mainly in the basis of the curriculum in all Islamic educational institutions. Particular attention was also paid to the memory development. Researchers also note a marked conservatism of traditional Islamic education, the rule therein scholastic teaching methods, the prevalence of the spirit of religious fanaticism and intolerance, etc., including Dagestan as an example as well [3]. So, a typical Muslim school pupil was far from being an active and thoughtful subject of the cognitive process. Moreover, many of the negatives of social and political tensions have a thorough soil in the conservatism and dogmatism of Muslim education.

The traditions and trends outlined prevent the Dagestan education from fitting into modern education, which now becomes a kind of complex conducting a continuous training at all levels, backed up by a new educational paradigm. I. A. Aleksandrov claims that the new educational model should address "the new formula of pedagogical learning: knowledge-skills-understanding of knowledge-creativity” [4].

Asubstantial transformation of the world picture at the turn of the millennia indicates the occurrence of a qualitatively new era. Obviously, the " $21^{\text {st }}$ century "model of education must undergo a radical transformation, and focus not on the past (conservatism), but on the future (futurism) of human civilization, also changing its development model” [5]. The main features of the new paradigm, in the opinion of different authors, should be: the change of the main semantic sign of education "rationalism" to the sign "culture"; the transition from the reproductive model of education, working on reproduction and stability of existing social relations, to a productive, culturally-oriented and humanistic model [6]. The humanization and humanitarianism should remain the leading trends in education nowadays.

The ideas of self-organization, self-development, self-determination, self-realization and self-actualization, proclaimed by synergy, humanistic philosophy and psychology, proved to be very popular in contemporary socio-cultural situation that determined the appearance of the concept of student-centered education, the essence of which is as follows: man is regarded as a complex self-developing system; the uniqueness of each individual and the trajectory of its development, its intrinsic value is recognized. This predetermined the reassess of the goals of education, which is shifted from the informatization of an individual to the creation of conditions and assistance in the development and self-development of a person on the whole, to the understanding of the world and himself, the self-determination in the environment and culture.

The essence of education within the cultural-centric concept of education (E.V. Bondarevskaya, A. S. Zapesotsky, S.Y. Kurganov, N. A. Lorya) is not the filling the memory with a certain amount of information and not even the development of intelligence, but the upbringing of the "spiritual instinct" that will help the person find the higher meaning of life. The result of education in this case is the spirituality of an individual as an absolute value of human life, the foundation of integrity and emotional health [7].

This concept "involves the understanding of education as a major social institution of cultural continuity; the expansion of the humanitarian core of the education through organic inclusion in the educational process of spiritual and moral potential of the Russian culture; the rise of the role of education as a mechanism for the formation of a "culture of viability", i.e. the psychological and moral readiness to live and work in a rapidly changing world, as a way to grow a creative person, a conscious subject of socio-cultural conversions; the optimal combination of professionalism and universalism; the focus on the principles of partnership and social responsibility, on the priority of the humanitarian and democratically oriented social technologies” [8].

These innovative concepts are particularly relevant in the current teaching of the humanities in the Russian education when the limits on the use of information technologies and test methods for organizing the USE in history, social studies, literature and other disciplines. The application of modern information, virtual technologies in the educational process is a powerful source of accessibility of educational and scientific information, a means of ordering of the teaching and educational processes, an effective lever of the backward and forward linkages of the teacher and the student, a reliable determinant of the contribution of each team member in a the common moneybox of success, a productive tool of visualization of the mechanisms of assimilation of knowledge, etc. We are talking about an excessive enthusiasm for the introduction of information technologies and testing methods in the educational process, thoughtless and formal approach, the need to comply with the measure in this regard, otherwise there occurs a kind of mechanization and technologization of thinking, when information and awareness substitute his intellect, his abilities of deep understanding of all dramaturgy of being. The existing test unification practice does not fit the standards of socio-humanitarian education; it does not fully take its specificity into account. 
Firstly, it is obvious that the socio-humanitarian knowledge does not lend itself to the same unique formalization as scientific. It is known that strict and complete formalization is impossible even for mathematics, where there would seem not to be any limits. And what can we say about the effective use of formal methods of teaching in the socio-humanitarian knowledge, if such constraints exist in mathematics? Secondly, the specific sociohumanitarian knowledge is expressed in the fact that it does not apply the traditional "two-valued", mathematical, or, as it is called, Aristotelian logic. Different, meaningful, valued or dialectical logic operates in the sociohumanitarian knowledge. The following feature of the socio-humanitarian knowledge is another, the third, argument in the defense of its position. We have in mind the separation of nomothetic and idiographic strategy in the methodology of knowledge imposed by Wilhelm Windelband, a representative of neo-Kantianism, to characterize the specificity of science and the humanities. The conclusion that in the socio-humanitarian knowledge there is not only some mechanisms of explaining, but also mechanisms of understanding, is the fourth important argument. The fifth feature of the socio-humanitarian knowledge, which is not included in the modern practice of testing under the USE is his dialogic principle, to be exact, polilogicality. Sixthly, the current practice of testing minimizes the possibility of emotional impact on students, especially with the use of hearing communication channels of people. Seventh, not all the things, especially in the humanitarian field, can be conveyed in words. The famous F. I. Tyutchev's phrase from the poem "Silentium!" "The thought expressed is a lie” fully reflects the fact that there is a discrepancy between the metaphor of a word and the content of thinking. The eighth argument is related to transcendence, another feature of the social and humanitarian knowledge. It is transcendence that can reveal such details of being that are not available to the traditional forms of understanding of the world and man, although it does not give an accurate and meaningful concrete knowledge. The ninth argument allows us to understand the methodological difficulties of applying test methods, especially in the final, exam stages of learning: the usual for us criteria of the truth do not act in the Humanities. The Humanities is not only a form of the scientific and theoretical knowledge, but also a form of ideology. Any worldview is deeply personal and unique. It does not fit into the Procrustean bed of any of the significant schemes.

Does the introduction of the formal methods of teaching Humanities help students and pupils attach to the skills of value dimension at least within their future profession? To put it mildly, not quite. And one of the main reasons for this situation in higher education is their "science like", subject-object teaching. Such a humanitarian education, assimilated to scientific schemes, as a prominent Soviet philosopher M. Mamardashvili noted at the time, should be prohibited in the education system. Teaching Humanities in the form of a subject-object relation, where at one Pole there is a teacher as the bearer of the absolute truth, and, at the other one, there is a listener, whose only thing to do is "catching roasted hazel-grouses of the absolute truth", is only a means of unanimity on certain ideological standards. A range of trendy test models of teaching only aggravate the situation, which in specific authoritarian traditions and language conditions is already complex in Dagestan. Both Humanities and social sciences, as a free coexistence of different forms of knowledge, have to be taught, studied only in the form of subject-object dialogue and just so a genuine science of man and society is possible. Thus, not only the tradition of Islamic education, but the negatives of contemporary secular, especially socio-humanitarian, education, complicate the relations of Dagestan with the rest of Russia, prevent an entry into the all-Russian and the world space of culture and civilization [9]. At the same time we are well aware that the guidelines for a unified educational space for Dagestan are determined not only by taking into account the Russian and the world civilization parameters, but they also pass through the Caucasian vectors. In our view, the process of formation of a unified educational space in the Caucasus and its subsequent entry into the world suggest a range of cultural backgrounds.

1) The peoples of the region will have to realize their deep, mental spiritual foundation and determine the monolith that defines the direction and nature of the development of culture and education. Joint efforts of scientists and politicians, responsible for the spiritual development of the society, are needed to make sense of the civilization prospects and the development of a social ideal.

2) Since joining the unified world educational space of the peoples of the region involves a dialogue of cultures and traditions, customs and mentalities, religions and educational systems, it is necessary to bear in mind that the Western path of civilized development, including European pedagogical traditions, may be unacceptable in terms of geopolitical clashes between Western and Eastern European, Muslim, Chinese and Hindu cultural and educational traditions in the Caspian region. According to the forecasts of political scientists in the next quarter of a century with intractable compromise sharpness, the West converge with the non-West, and more specifically, with the Islamic and Buddhist worlds, whose value consciousness congeniality several times greater 
than the degree of interconnectivity of cultural ideals of each of them as compared with the European ones.

3) Remarkable and specific for the region is the fact that today pedagogy and philosophy of education should guide the school to reject Western values such as the rational absolute role in the spiritual life, the priority of practical success in human activity, the reassessment of personal freedom and appropriately interpreted humanism, which have overshadowed the West and in the East and the Muslim world has never been the primary values. In our opinion, the Russian regions have stimulated the effect of these values to the detriment of the historical traditions to justify themselves by joining the Bologna Declaration, the essence of which is the formation of a unified European educational space and the European system of education.

4) The educational and cultural policy of Dagestan and Muslim Caucasusas well, must also come from the fact that in a pluralistically formed human subjectivity and growing tolerance to its content of the values of the Eastern culture as attribute parameters of the human spirit, a situation of free selection of a corresponding option of the spectrum of cultural and educational ideals of the peoples of the region is created. And here it is important to preserve and defend truly promising humanitarian values and pedagogical ideals, but not any of their own. For example, such a legacy of the Omayyad and Abbasid Empire times as separate gender training, emphasis on the memorization of texts and scholastic teaching methods, authoritarian traditions in Muslim pedagogy, transforming a student into a "vessel of knowledge", is unlikely to have a perspective. Effective and promising subject-object relationship in knowledge and education, the transition from a student-recipient and a relay of the information to the active subject knowledge and to the pedagogy of trust and cooperation is also a challenge for education in Muslim countries in the $21^{\mathrm{st}}$ century. The task of the cultural and educational continuity of training in education is, perhaps, the most difficult problem in finding an educational basis. The globalization, on the one hand, stimulates updates in high school, and on the other hand, breaks down not only the traditional structures and functions of the educational system, but also the values of the ethnic culture. In Dagestan itself the ideologists and the intellectual elite tend to gloss over the historical past of the native ethnic groups, to idealize their customs and traditions, to exaggerate their role in the prospects of education, but, as you know, even the generally accepted spiritual values are unequally important for the peoples of the republic. If the collective responsibility, the respect for elders and the patriotism are the primary values for Eastern and Muslim cultures, they are secondary or even irrelevant, for the West. However, there are also some contradictions between Eastern and Muslim cultures, but they are less visible. Peacefulness, preserving the environment, the sanctity of an arable land, karma, much appreciated in Buddhism is not so valuable for a Muslim.

5) We shouldn't also forget the fact that the religious trend, becoming more important in modern education, is important for the Caucasus. If the Western Catholic tradition is bringing up an active person, the Eastern European Orthodox culture emphasis is on spiritual development, and in Islam-on the ideas of self-improvement. These ideas developed in the book by al-Ghazali "Resurrection of the sciences on faith" as the need for ethical education along with training in the educational process are not the only important ones in the modern Muslim world. The features of the national mind and the ethnic components of the learning culture of the Eastern peoples are defined largely, anyway, more than the Europeans, by religious traditions. Modern education should speak of the sphere of social life, which will be a synthesis of all the three positive religious tendencies, especially since in all the cultures religion has quite high reputation. The fruitful union of religions in the name of effective education should prevent the spread of misconceptions about each other: in particular, a popular in the Christian world philistine opinion about the aggressiveness and brutality of Islamic installations is rejected by an objective analysis, but still finds its adherents even in the scientific community. Hence, the whole problem of terrorism and the associated with it by public opinion problem of collision of religions and civilizations should be a global concern of education.

Today Europe is going through changes comparable only to that of the industrial revolution. Digital technologies, biotechnologies, development of communication networks and the expansion of trade-all those things provide great opportunities for personal development, but also contain a huge risk. People have more freedom in shaping their lifestyle, but it imposes greater responsibility for their own lives. The gap between those, who succeed in the labor market, constantly maintain and update their skills, and those, who are hopelessly behind, not keeping up with rapidly growing professional requirements, increases. All these changes can be described as the sum of the transition to "a society based on knowledge" or information society; that is, one where intangible goods and services form the basis of the economy, where knowledge and skills become paramount. Continuing education considers the process of learning as a constant continuum "from cradle to death.” Those basic skills that a person receives in his youth, serve as its foundation. These skills need to be revised and expanded in the 
information society. The ability to learn and continue the education on individually should be added to it.

However, all these factors of economy and culture today are not taken into account in educational policy and educational organization is largely subject to inertia and formality. For decades training of educators in Dagestan has been carried out, based on the fact that in villages and towns there are not enough teachers of physics, chemistry, history, Russian or English, etc. Several of our leading universities, without reducing speed, accept and produce hundreds of historians, physicists, mathematicians, etc. But they are still needed in the rural districts of the republic, as it was before. And everyone knows the main reason. It's low wage of a school teacher. The higher educational institutions are working for nothing. Furthermore, the considerations which form the basis of annual figures of the enrollment of students in universities, for many years are the same: the requirements of the Federal Ministry of Education and Science, the requests of the republican ministries (primarily education), the prestige and trendy specialties, which have traditionally a high competition, etc.

They also say that we do not have enough lawyers and economists, and those who have already graduated are overwhelmingly unemployed, or just poorly prepared. But for many years we have been observing that hundreds and thousands of graduates of these areas of education only replenish corruption spheres of our society and enhance the tension, which is already high in the society. It is transmitted to the universities in the form of imaginary needs of unprepared young people for the training and their thirst to those fashionable specialties by right or wrong, and then to school, where the taint of corruption firmly settled down in secondary education up to the USE.

It is necessary to reduce the admission to the traditional departments or radically modify their contents with new professions and specializations related to the information technologies. Let's say, a physics teacher can be prepared with an additional speciality "computer science" and a mathematician with the speciality "computer security".

I highly appreciate the importance of the basic math and science education for the worldview and scientific establishment of a scientist, but we must understand that the number of employed specialists of a given profile in material production has been steadily declining due to a sharp increase in technical labor productivity due to an extensive use of computers. At the same time, the trend toward the humanization of education in Soviet times has recorded twist of the modern society to the value-oriented science and education. And today the i's are dotted and the t's are crossed and a new conceptual framework has been developed in the philosophy of science that reflects some clearly turning trends in science.

The need for "environmental imperative" in scientific, technical and industrial activity, for example, is evident. Not only a large-scale production, but also small technical businesses are now inconceivable without an environmental and socio-humanitarian examination of scientific and technical projects that require a considerable number of professionals of an entirely new level. Environmental Ethics establishes norms of relations between man and nature, providing moral foundations of nature. It is generally accepted in developed countries that almost all working people must possess it, but the corresponding culture should be taught. The intensity of information in the modern world and the associated worsening of psychological problems, fatigue syndrome information also require limiting convergence between technical sciences and humanities, and this should be reflected in university education. More phraseological, valueological and social requirements are imposed today to the newly created man-made objects, human-computer interaction, which is impossible without philosophy, psychology and pedagogy; the society is increasingly paying attention to the negatives of the utility maximization with the help of liberal education. All this is due to the need to prepare completely new professionals with a solid humanitarian education for the industry.

Late 20th and early 21st centuries were marked with a qualitative scientific knowledge in the interweaving of personal, social and cultural dimensions of the knowing subject. The science and education are trying to fix a set of external factors, which can impart different characteristics of the laws of the structure and of the development of the society through the concepts of the geomedium and the ethnosphere. At the same time, a stable complex of mental and behavioral traits, which is invariant for different ages and ethnic groups, has a noticeable effect on human behavior. This complex is called the passionarity. Passionarity as a special kind of energy, as a measure of the activity of ethnic groups or as individual behavioral imperative captures the impact of man on nature and society, which should certainly be taken into account not only by humanitarian, but also by natural and technical sciences. Cloning and nanotechnology, coevolution and virtualistics combine in its facilities realities of very different nature, such as physical, psychological, social, political, etc., thus specifying pairing of anthropocentric 
and cosmocentric perspectives of research activities. Not only the convergence of ideals of science and sociohumanitarian knowledge, but also a crisis of ideals of evaluative and neutral study appears in all of this, and the problem of ideological science is facing. A blasphemous and unacceptable for classical science dominance even in natural science of norms, standards, techniques, methods and ideals of social and humanitarian cognition occurs. All these not projected in the recent past transformations in science should find appropriate consequences in higher and secondary education, in the broad public consciousness and in the culture of the society.

Sharp increase in the need for admission to universities on environmental, psychological and philosophical discipline in Dagestan is obvious because violent and not always positive transformations take place in our society. The need to promote environmental awareness and appropriate behavioral culture needs no justification, since we need to save the flora and fauna of Dagestan, even his highland villages will soon be drowned in the mud and antisanitary. Psychological education should contribute to changing the culture of relations between our Dagestani; gradually eliminate our spirit of fervor and intolerance, categorical and other negative elements of mentality. A preparation of exotic in the recent past specialists—philosophers, political scientists, sociologists, culturologists and theologians is relevant today as never and nowhere in North Caucasus and Dagestan. All of our socio-political tragedy destabilizing social existence and claiming hundreds of lives and thousands of innocent people in the past decade is due to no natural aggressiveness or genetic propensity for extremism of the indigenous peoples of the region, but have the character of ideological and philosophical origins and differences that in a civilized society should be adjusted and harmonized in scientific, party and political discussions. For this, as an experience shows, few intellectuals of these specialists are not enough; mass release of appropriate people with a quality of higher education is needed.

In Russia, including Dagestan, they switched to the study of a new compulsory subject in schools. The subject will be called "Spiritual and moral education". Who will do this at school? We are said: "We retrain some definite number of teachers for definite time and for some definite quantity of money." All this is a reminiscent of another unrealizable Utopia, as a result, good intentions can be turned into a massive penetration of primitivism and obscurantism in the secondary school. For many years we have been trying to solve a previous similar problem in a high school, but until recently social science subjects are taught at a low level from the 6th grade to the graduating class such as Economics, Law, Culture, Logics, Ethics, Esthetics, History of Religion and so on. It's high time to start preparing the relevant teachers. Not only the educational institutions, but also the government apparatus and the People's Assembly, the Ministries of: Culture, Education, Information, National and External Relations, for Youth Policy, the Committee on Religious Affairs and their departments need graduates of these specialities today. Not physicists, linguists, historians or the representatives of other private scientific knowledge must work there, but those who know modern public relations, social structure, personality psychology, culture, religion, politics, who are versed in the trends of the information society and globalization. The effectiveness of the education of a physicist or a lawyer is realized mainly in practice. The effectiveness of a psychologist, a culturologist and a philosopher is realized not only in their professional activities, but also in everyday life, in dealing with small and large societies. An unemployed physicist or a lawyer turns, as a rule, into a person who spent time and energy on unproductive for the soul and spirit education, while listed in humanitarians, even if they have not found a job yet, are prepared spiritually for self-sufficient personal and microstructural functioning, they are valuable for a social and cultural development of the society. The Humanities training is a sure win both for the state and for an individual. That is why they must exceed the total number of students admitted to the university. Thus, the traditions and trends of the Dagestan education today form a concrete historical comprehensive system permeated many contradictions. Their solution requires common efforts of scientists, politicians and coordinators of science and education.

\section{References}

[1] http://www.riadagestan.ru/news/in_russia/rosobrnadzor_opublikoval_spisok_lits_dopustivshikh_narusheniya_na_ege/

[2] (2004) History of Dagestan from Antiquity till Today. Book 1, 588-590.

[3] Kymarazov, G.Sh. (2001) Muslim System of Education in Dagestan. Islam and Islamic Culture in Dagestan.

[4] Aleksandrov, I.A. (2002) Philosophical Conception of Higher Education: To Organization New Educational Models. Philosophy of Education, No. 5, 59.

[5] Ursul, A. and Romanovich, A. (2003) World Summit on Sustainable Development: Results, Hopes, Perspectives. Alma Mater (Bulletin of High School), No. 4, 4. 
[6] Valitskay, A.P. (1998) Culture-Creative School: Conception and Model of Educational Process. Pedagogics, No. 4, 12.

[7] Zapesotsky, A.S. (2002) Liberal Education and Problems of Spiritual Safety. Pedagogics, No. 2, 323.

[8] Zapesotsky, A.S. (2002) Liberal Education and Problems of Spiritual Safety. Pedagogics, No. 2, 324.

[9] Bilalov, M.I. (2003) The Single Educational Space. Globalistics. Encyclopedia. Ed: Masur I., A.N. Chumakov.-M., 326-327. 
Scientific Research Publishing (SCIRP) is one of the largest Open Access journal publishers. It is currently publishing more than 200 open access, online, peer-reviewed journals covering a wide range of academic disciplines. SCIRP serves the worldwide academic communities and contributes to the progress and application of science with its publication.

Other selected journals from SCIRP are listed as below. Submit your manuscript to us via either submit@scirp.org or Online Submission Portal.
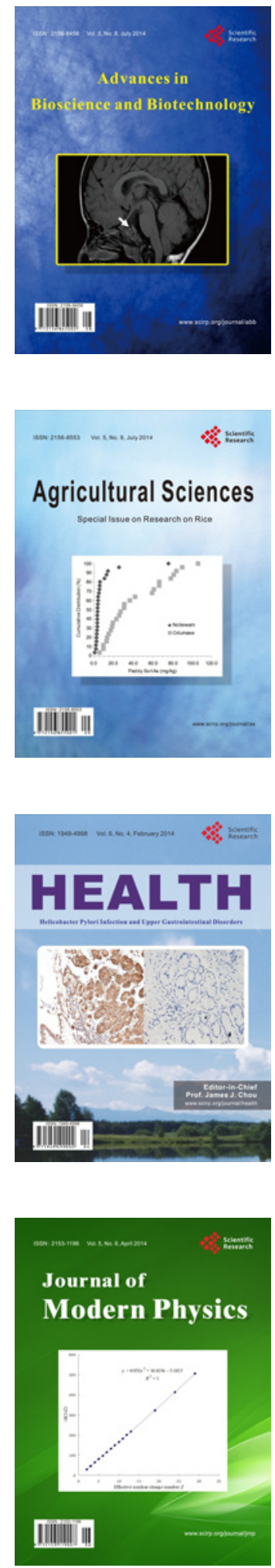
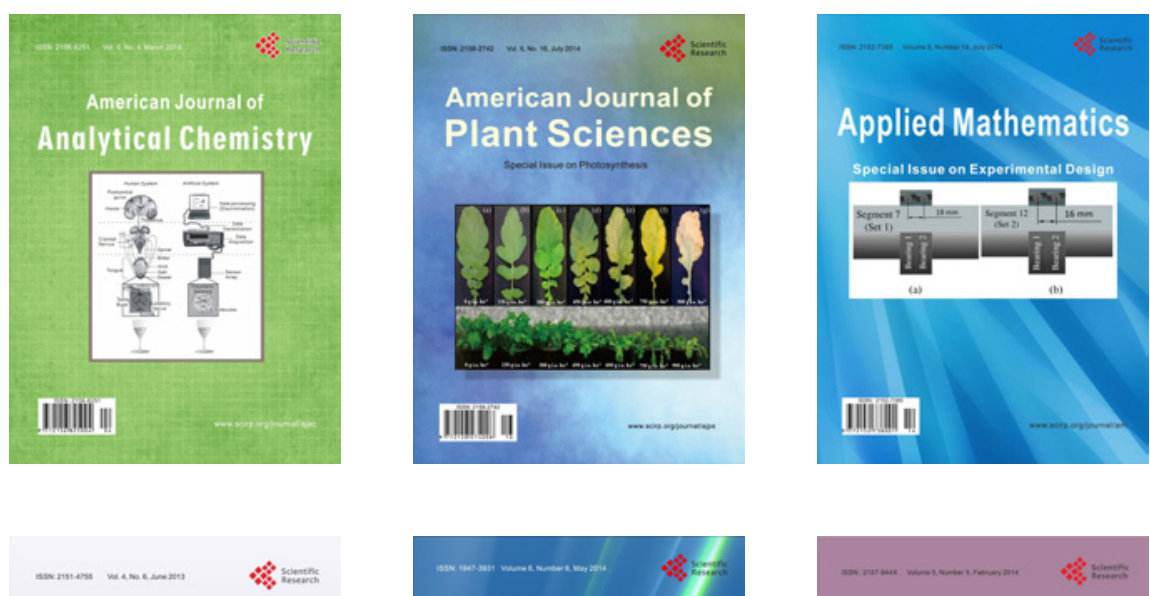

Creative Education
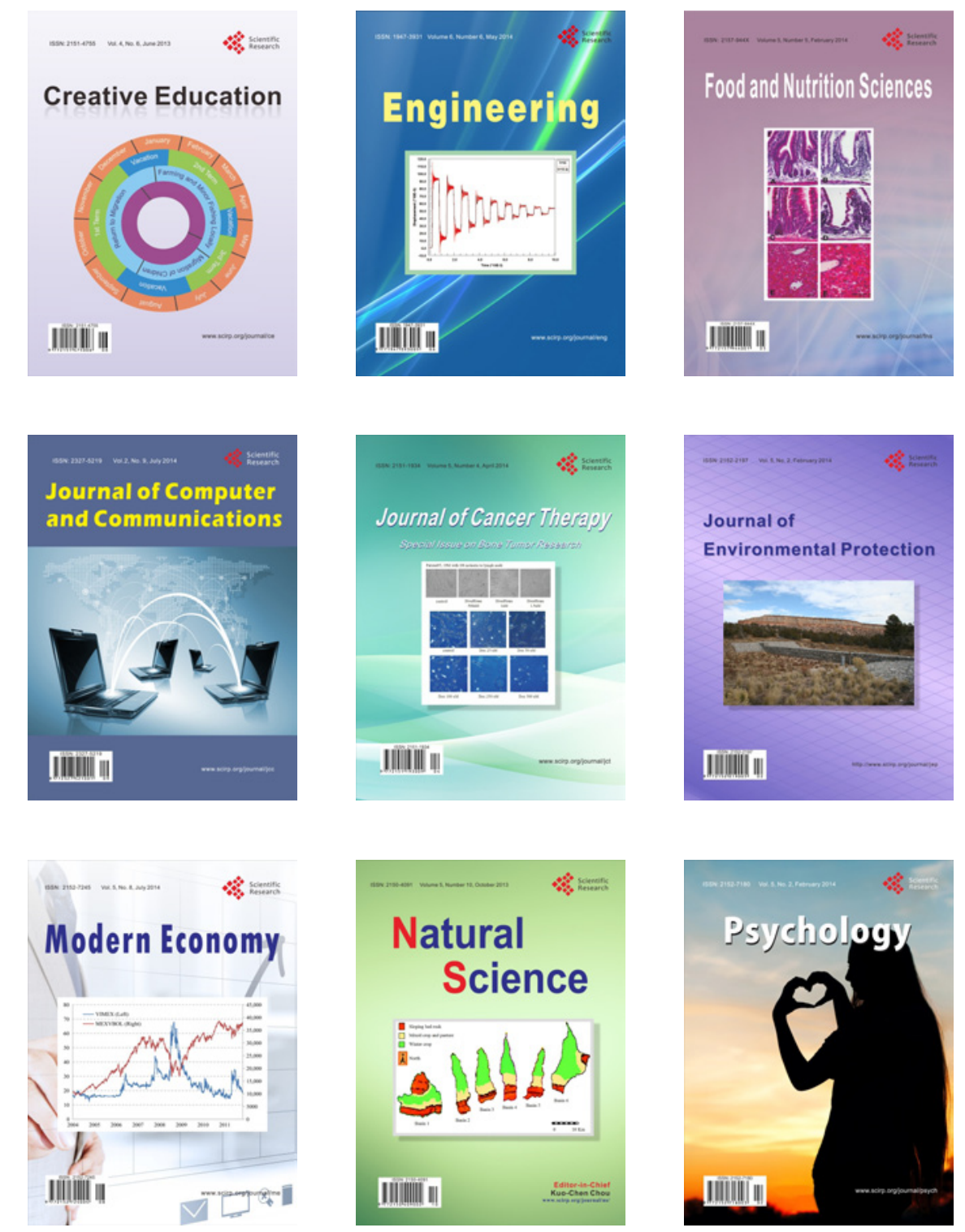